\title{
Can Universities Improve their Competitiveness using Information Technology?
}

\author{
Galih Abdul Fatah Maulani, Nizar Alam Hamdani
}

\begin{abstract}
Rapid changes in information technology happen in today's era of Society 5.0 and the Industrial Revolution 4.0. Universities are expected to adapt to these changes to maintain their existence. This study examines the relationship between information technology use and organizational competitiveness in higher education. Quantitative data were collected from 29 private universities in Indonesia. Data analysis was performed using $P L S-S E M$. The results revealed that information technology, consisting of Information Quality, System Quality and Service Quality, had significant positive impact on the competitiveness of universities in Indonesia. This implies that it is necessary for universities to optimize the application of information technology in their business processes in order to improve competitiveness in the era of Society 5.0 and the Industrial Revolution 4.0.
\end{abstract}

Index Terms: Competitiveness, Higher Education, Information Technology.

\section{INTRODUCTION}

Information Technology is a strategic potency in the current industrial revolution that plays an important role in creating organization sustainability (1)(2). Organization administrative is required to have good performance in a competitive market challenge (3). This also applies to non-profit organizations such as universities (2). The contemporary trend of universities in Indonesia is developing. This is characterized by the increasing number of universities in Indonesia.

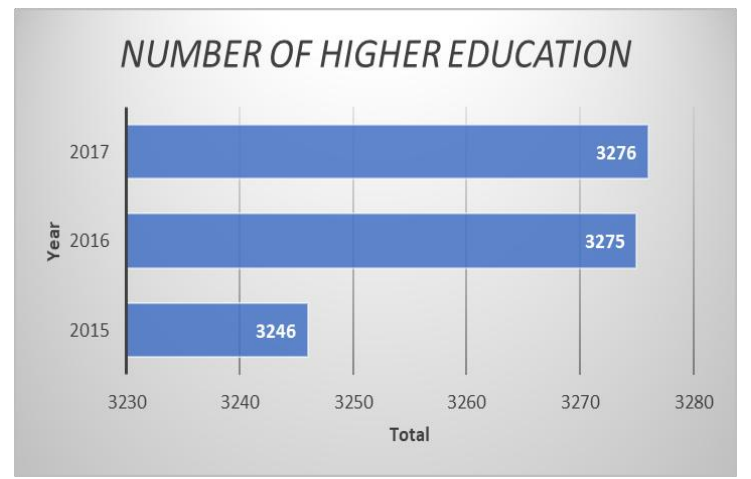

Figure 1. The Increasing number of universities is in Indonesia in the last 3 years (4)

Ministry of Research, Technology and Higher Education of the Republic of Indonesia reported that the number of both private and state universities in Indonesia is 3,276. They are spread throughout Indonesia and the most concentration is

Revised Manuscript Received on September 22, 2019.

Galih Abdul Fatah Maulani, Entrepreneurship Faculty, Universitas Garut, West Java, Indonesia.

Nizar Alam Hamdani, Economic Faculty, Universitas Garut, West Java, Indonesia. located in Java (4). The number of higher education is increasing every year. It creates more competitions among universities. Higher education is expected to be more competitive by creating new business processes and values beneficial to its stakeholders (5). Information technology is one of the most strategic factors in creating the university competitiveness in overlooking a competition and determining the success of an organization (6).

However, universities are imprisoned in a condition wherein information technology is built more on "wants" rather than "needs" of the university management system (7). This makes the information system or information technology merely decorate and impede business processes because it is not in conformity with the organizational functionality needs. For that reason, this study attempts to reveal the influence of information technology on the university competitiveness

\section{LITERATURE REVIEW}

Competitiveness was the center of attention and studied intensively by researchers in the 1980s and 1990s. Some studies emphasized more on organization that had resources, rare and infinite values, innovation, strategic assets and reputation $(8,9)$. In some literatures of classical strategy models, external factors and internal factors are a combination of complex phenomena in creating competitiveness (10). Principally, the concept of competitiveness believes that an organization is supposed to predominate other similar organizations (11). In addition, competitiveness is referred to as the level of competence that has relevance to other competitors which includes such parameters as technology, knowledge, level of strategic and operational planning, and staff skills and the quality of management systems (12).

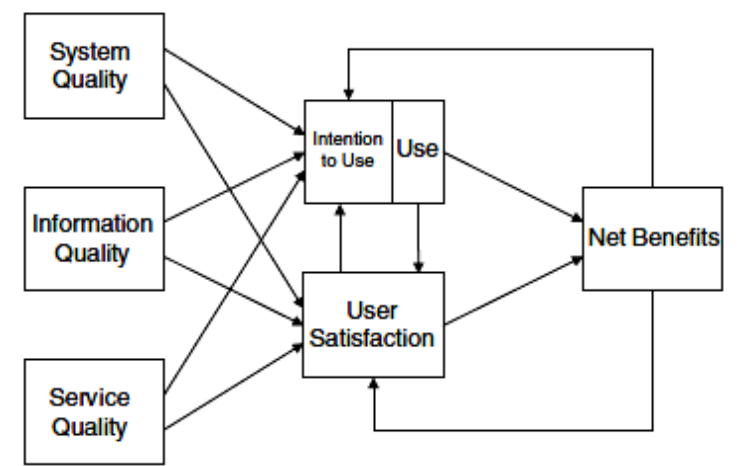

Figure 2. Updated DeLone and McLean IS success model

Information technology is one of the important tools in the service activities in a company (1). In addition, It is an important strategic resource for organizations, including universities. This makes a very

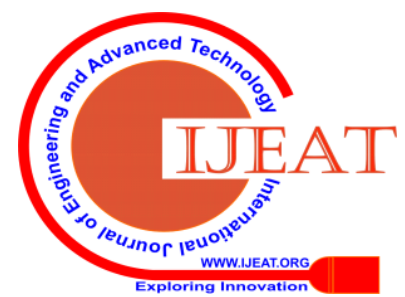


positive contribution to information that has an impact on decision making (14). Information technology can be measured and analyzed using several indicators including information quality, quality system and quality of service (15). This is in line with several previous studies $(2,16)$.

\section{METHODOLOGY/MATERIALS}

This research was a verification study involving data from 29 universities under the Ministry of Research, Technology and Higher Education of the Republic of Indonesia in West Java Province, specifically in Garut, Tasikmalaya and their surroundings. The sample was taken using non probability sampling technique. The data were processed using SEM-PLS. This research involved several observed variables that can be illustrated in the following table.

Table 2. Research Variables

\begin{tabular}{|c|c|c|}
\hline VARIABEL & INDICATOR & SOURCE \\
\hline \multirow{9}{*}{$\begin{array}{l}\text { Competitiveness } \\
\text { (Y) }\end{array}$} & Technology (Y1) & \multirow[t]{9}{*}{ (12) } \\
\hline & Knowledge (Y2) & \\
\hline & Staff Skills (Y3) & \\
\hline & Strategic and & \\
\hline & Operational planning & \\
\hline & $(\mathrm{Y} 4)$ & \\
\hline & Management System & \\
\hline & Quality (Y5) & \\
\hline & $\begin{array}{l}\text { Communication } \\
\text { (Y6) }\end{array}$ & \\
\hline \multirow[t]{3}{*}{$\begin{array}{l}\text { Information } \\
\text { Technology (X1) }\end{array}$} & $\begin{array}{l}\text { Information Quality } \\
\text { (X1) }\end{array}$ & \multirow[t]{3}{*}{ (5) } \\
\hline & System Quality (X2) & \\
\hline & Service Quality (X3) & \\
\hline
\end{tabular}

\section{RESULTS AND FINDINGS}

The analysis was conducted to examine the influence of information technology on the university competitiveness in Indonesia. The data was processed using SmartPLS software. What follows is the result of SEM-PLS modeling analysis:

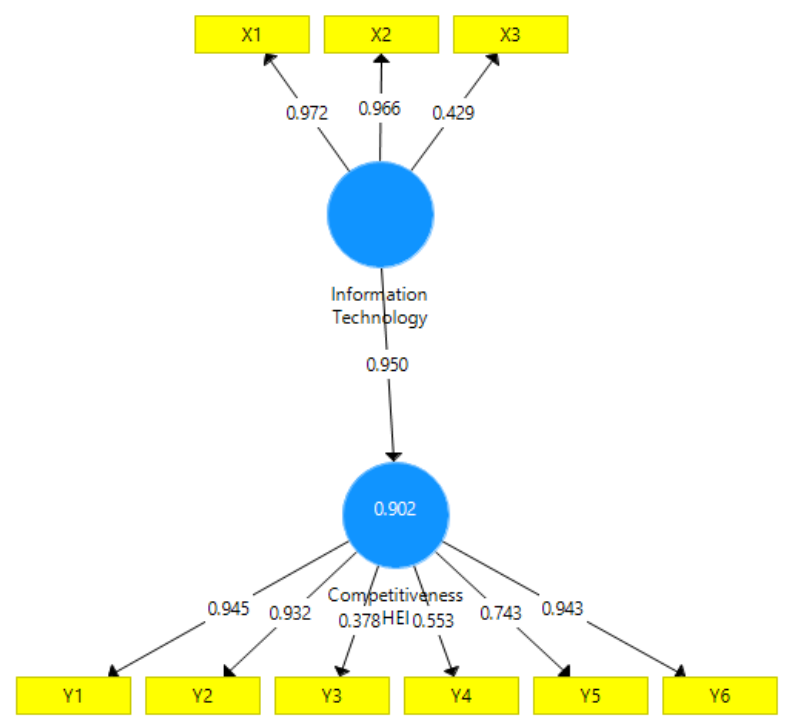

Figure 2 PLS Modeling
Based on PLS calculation and analysis, as presented in Figure 2, there were several interpretive indicators. The coefficient of information technology to competitiveness variable was 0.950 . This indicated that the influence of IT variables on Competitiveness HEI was 0.950. Based on calculations, there are also values of each indicator. The following description detailed the values in question.

Information Technology variable (X) had loading factor values on each indicator, among others: Information Quality (X1) of 0.972, System Quality (X2) of 0.966, and Service Quality (X3) of 0.429. In addition, competitiveness variable had loading factor values on each indicator, including: Technology (Y1) of 0.945 ; Knowledge (Y2) of 0.932; Staff Skills (Y3) of 0.378; Strategic and Operational planning (Y4) of 0.553; Management System Quality (Y5) of 0.743 and the Communication indicator (Y6) has a loading factor value of 0.943 .

Based on figure 2, each indicator of each variable is supposed to outscore 0.50 to be considered reliable. The indicators with a loading value lower than 5 are Service Quality (X3) and Staff Skill (Y3) indicators. This made the indicator removed from the PLS model. Likewise, discriminant validity indicators can be analyzed from the cross loading value between the indicator and its construct. There are several results displayed on the SmartPLS, these results include the matrix as follows:

Table 3 Construct Reliability and Validity

\begin{tabular}{l|llll}
\hline & $\begin{array}{l}\text { Cronbach's } \\
\text { Alpha }\end{array}$ & $\begin{array}{l}\text { rho_ } \\
\text { A }\end{array}$ & $\begin{array}{l}\text { Composit } \\
\text { e } \\
\text { Reliability }\end{array}$ & $\begin{array}{l}\text { Average } \\
\text { Variance } \\
\text { Extracted } \\
\text { (AVE) }\end{array}$ \\
\hline $\begin{array}{l}\text { Competitiveness } \\
\text { HEI }\end{array}$ & 0.892 & 0.955 & 0.921 & 0.706 \\
$\begin{array}{l}\text { Information } \\
\text { Technology }\end{array}$ & 0.956 & 0.956 & 0.979 & 0.958 \\
& & & & \\
\end{tabular}

There is an alternative to validate a variable or construct by looking at the value of Average Variance Extracted (AVE) which is required to be higher than 0.50 The computation showed that the competitiveness variable was 0.706 and information technology was 0.958 . This ascertains that these variables were valid and met the requirements of having an AVE value higher than 0.50.

The analysis was continued to the variable reliability test measured and analyzed through composite reliability criteria and Cronbach Alpha. A reliable variable should have Composite Reliability and Cronbach Alpha higher than 0.7. Based on calculations in table 3, the value of Composite Reliability in the Competitiveness HEI variable was 0.921 and the Information Technology variable was 0.979 . Whereas the Cronbach Alpha value on Competitiveness variable was 0.892 and Information Technology variable was 0.956 . It can be concluded that the Competitiveness and Information Technology variables were reliable.

Further test was carried out for the inner model. The test was undertaken by looking at the R-Square value which manifests the Goodness-fit model test 
Table 4. R Square

\begin{tabular}{lcc}
\hline & R Square & \multicolumn{1}{l}{$\begin{array}{l}\text { R Square } \\
\text { Adjusted }\end{array}$} \\
\hline $\begin{array}{l}\text { Competitiveness } \\
\text { HEI }\end{array}$ & 0.930 & 0.927 \\
\hline
\end{tabular}

The PLS modeling pointed out that the effect of information technology on university competitiveness in Indonesia had an R-Square value of 0.930. This elucidated that information technology can explain the variability of competitiveness by $93 \%$ while the other $7 \%$ is explained by other unknown variables.

The next step was to test the significance of the influence of information technology on university competitiveness in Indonesia. Based on the parameter coefficient and the significance value of $\mathrm{t}$ statistics, the PLS Model was first bootstrapped to produce statistical data as follows:

Table 5. Mean, STDEV, T-Values, P-Values

\begin{tabular}{lllccr}
\hline & $\begin{array}{l}\text { Original } \\
\text { Sample } \\
(\mathbf{O})\end{array}$ & $\begin{array}{l}\text { Sample } \\
\text { Mean } \\
(\mathbf{M})\end{array}$ & $\begin{array}{l}\text { Standard } \\
\text { Deviation } \\
\text { (STDEV) }\end{array}$ & $\begin{array}{l}\text { T Statistics } \\
(\text { (O/STDEV })\end{array}$ & $\begin{array}{r}\text { P } \\
\text { Values }\end{array}$ \\
\hline $\begin{array}{l}\text { Information } \\
\text { Technology_-> } \\
\text { Competitiveness }\end{array}$ & 0.964 & 0.968 & 0.008 & 127.303 & $\mathbf{0 . 0 0}$ \\
HEI & & & & & $\mathbf{0}$ \\
\hline
\end{tabular}

Based on the calculation results, the value of the original sample was 0.964 . This indicated that there was a positive influence from Information Technology on Competitiveness HEI. This indicates that the more information technology is integrated, the higher the competitiveness of the universities will become. In addition, statistical $\mathrm{T}$ value of 127,303 which is greater than the $\mathrm{t}$ critical value of 1.96 was also obtained. Thus, it can be concluded that Information and system quality in information technology had a very significant relationship with technology, knowledge, strategic and operational planning, management system quality and communication on university competitiveness.

\section{CONCLUSION}

Information technology has become one of the competitive resources for universities in Indonesia. The quality of information technology is down to the quality of information including comprehensive, real-time, relevant, and user friendly information system. In addition, the implementation of information technology in HEIs should also be taken into account so as to produce quality system because that would positively affect the HEI competitiveness.

\section{REFERENCES}

1. Ismaeel N, Siron R, Zahari I, Khalid M. Impact of Information Technology Infrastructure on Innovation Performance: An Empirical Study on private Universities In Iraq. 2016;39(November 2015):861-9.

2. Maulani GAF, Hamdani NA. Perencanaan Strategis Sistem Informasi pada Perguruan Tinggi Swasta di Indonesia ( Studi Kasus pada Institut Pendidikan Indonesia Garut ). J PETIK [Internet]. 2018;4(September):162-6. Available from: https://journal.institutpendidikan.ac.id/index.php/petik/article/view/3 67

3. Hamdani NA, Susanto T, Abdul Fatah Maulani G. Framework of
Architectural Marketing Capabilities in Regional Development Bank Int J Eng Technol [Internet]. 2018;7(3.25):166-9. Available from: https://www.sciencepubco.com/index.php/ijet/article/view/17539

4. Kementerian Pendidikan Tinggi. Statistik Pendidikan Tinggi 2017. Jakarta: Pusat Data dan Informasi Iptek Dikti; 2017. 194 p.

5. Chen J, Tsou H. Journal of Engineering and Performance effects of IT capability, service process innovation, and the mediating role of customer service. J Eng Technol Manag [Internet]. 2012;29(1):71-94. Available from: http://dx.doi.org/10.1016/j.jengtecman.2011.09.007

6. Dangolani SK. The effect of information technology in the entrepreneurship (a case study in Golestan province IRAN). Procedia Soc Behav Sci. 2011;30:10-2.

7. Paul Legris, John Ingham PC. Why do people use information technology? A critical review of the technology acceptance model. Inf Manag. 2003;40(2003):191-2014.

8. Ketels DC. Review of Competitiveness Frameworks. Dublin: National Competitiveness Council; 2016. 58 p.

9. Matthews J, Shulman A. Competitive advantage in Public sector organizations : Explaining the public good / sustainable competitive advantage paradox i Competitive advantage in Public sector organizations : Explaining the public good / sustainable competitive advantage paradox. J Bus Res. 2005;58(2):232-40.

10. Mainardes EW, Ferreira JM, Tontini G. Creating a competitive advantage in Higher Education Institutions: proposal and test of a conceptual model. Int J Manag Educ [Internet]. 2011;5(2/3):145. Available from: http://www.inderscience.com/link.php?id=39482

11. Mao H, Liu S, Zhang J, Deng Z. International Journal of Information Management Information technology resource, knowledge management capability, and competitive advantage : The moderating role of resource commitment. Int $J$ Inf Manage [Internet] 2016;36(6):1062-74. Available from: http://dx.doi.org/10.1016/j.ijinfomgt.2016.07.001

12. Kireeva N, Slepenkova E, Shipunova $\mathrm{T}$, Iskandaryan $\mathrm{R}$. Competitiveness of higher education institutions and academic entrepreneurship. Espacios. 2018;39(23):15.

13. Petter S, DeLone W, McLean E. Measuring information systems success: Models, dimensions, measures, and interrelationships. Eur J Inf Syst. 2008;17(3):236-63.

14. Mitić S, Nikolić M, Jankov J, Vukonjanski J, Terek E. The impact of information technologies on communication satisfaction and organizational learning in companies in Serbia. Comput Human Behav. 2017;76:87-101.

15. Abrego Almazán D, Sánchez Tovar Y, Medina Quintero JM. Influence of information systems on organizational results. Contaduría y Adm [Internet]. 2017;62(2):321-38. Available from: http://www.cya.unam.mx/index.php/cya/article/view/1461

16. Ashrafi R, Murtaza M. Use and Impact of ICT on SMEs in Oman. Electron J Inf Syst Eval [Internet]. 2008;11(3):125-38. Available from:

http://www.ejise.com/volume-11/volume11-issue3/ashrafiAndMurtaz a.pdf

\section{AUTHORS PROFILE}

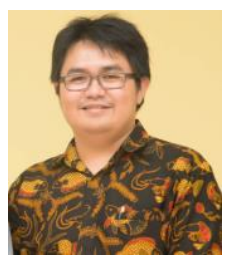

Galih Abdul Fatah Maulani. lecturer at Fakultas Kewirausahaan Universitas Garut, Indonesia. His research interests include business information system, strategic management, technopreneurship and information technology..

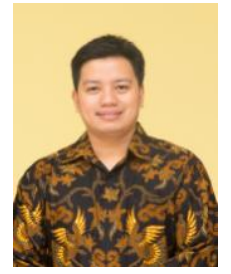

Nizar Alam Hamdani. lecturer at Fakultas Ekonomi Universitas Garut. His research interests include strategic management, knowledge management, entrepreneurship, and SMEs. 